\title{
Checklist of bees (Apoidea) from a private conservation property in west-central Montana
}

\author{
Marirose Kuhlman ${ }^{\ddagger}$, Skyler Burrows $§$ \\ ‡ MPG Ranch, Florence, MT, United States of America \\ $\S$ Bee Biology and Systematics Lab, Logan, UT, United States of America
}

Corresponding author: Marirose Kuhlman (mkuhlman@mpgranch.com)

Academic editor: Michael Kuhlmann

Received: 15 Dec 2016 | Accepted: 22 Mar 2017| Published: 30 Mar 2017

Citation: Kuhlman M, Burrows S (2017) Checklist of bees (Apoidea) from a private conservation property in west-central Montana. Biodiversity Data Journal 5: e11506. https://doi.org/10.3897/BDJ.5.e11506

\begin{abstract}
\section{Background}

Here we present preliminary results from the first three years of a long-term bee survey conducted at a 3,840-ha private conservation property in the northern Sapphire Mountains and Bitterroot River Valley, and a pilot study at an associated 80-ha property in the Swan River Valley, Missoula County, Montana, USA. The survey includes hand-net, bowl-trap, and blue-vane trap collections. The resulting checklist comprises 229 bee species and morphospecies within 5 families, 38 genera and 91 subgenera. Of the total species in the list, 34 of them represent first state records Montana. This survey expands the number of bee species recorded in Montana to 366. Included in these species is Megachile (Eutricharaea)) apicalis Spinola, showing a range expansion for this introduced bee.
\end{abstract}

\section{New information}

We present new distributional records for 34 bee species, including Megachile (Eutricharaea) apicalis Spinola, an introduced bee that was discovered to be resident in North America in 1984 in Santa Barbara County, California. This species has since 
expanded its range in the across the west, but had not been previously recorded in Montana.

\section{Keywords}

Hymenoptera, biodiversity, pollinator, native species, invasive species, adventive, range expansion, introduced, Megachile apicalis, North America, Intermountain West

\section{Introduction}

Wild bees play a vital role as pollinators in both agricultural and natural systems, and may be important to the success of habitat restoration projects (Menz et al. 2011, Williams 2011). Work has been done to document bee faunas of some western regions of North America, including Colorado (Scott et al. 2011), the Columbia Basin (Tepedino and Griswold 1995), north-central Washington (Wilson et al. 2010), and some US national parks and monuments (e.g. Messinger and Griswold 2002); but there are few large-scale bee surveys from Montana.

Reported here is the bee species list from the first three years of a long-term bee monitoring study we initiated in 2013 at MPG Ranch, a privately-owned conservation property in the northern Bitterroot Valley and Sapphire Mountains, and a pilot study from MPG North, an associated property in the Swan Valley. Both properties are in Missoula County of west-central Montana. A purpose of this study is to inventory the bee fauna on the properties.

\section{Materials and methods}

\section{Study Site}

The 3,840 hectare MPG Ranch is a privately-owned conservation property in west-central Montana, in the Bitterroot River Valley and Sapphire Mountains of Missoula County (Fig. 1). Elevations range from $975 \mathrm{~m}$ at the valley floor along the Bitterroot River, to $1860 \mathrm{~m}$ on Mount Baldy, its highest point. The region has a mild, semi-arid climate with cool, moist winters and warm, dry summers. Mean precipitation ranges from $300 \mathrm{~mm}$ at the valley floor to $350 \mathrm{~mm}$ on mountain summits; most precipitation occurs in the winter as snow. Mean temperatures for the nearby town of Stevensville range from $-3.6^{\circ} \mathrm{C}$ in December to $20.0^{\circ} \mathrm{C}$ in July.

For over a century prior to 2009, this property had been managed for livestock and agricultural crop production. During that time, most of the lower elevation grasslands were replaced with irrigated crops or introduced forage grasses. These areas are now out of production and undergoing restoration treatments to return them to a more natural state. Livestock has also been removed from the property as part of the restoration effort, and 
native ungulates (elk, mule deer, and whitetail deer) currently comprise the majority of vertebrate grazers. Habitats on the property include riparian bottomlands, dry open forests, mid-elevation sagebrush steppe and grasslands, montane grasslands, and montane mixed-conifer forest.

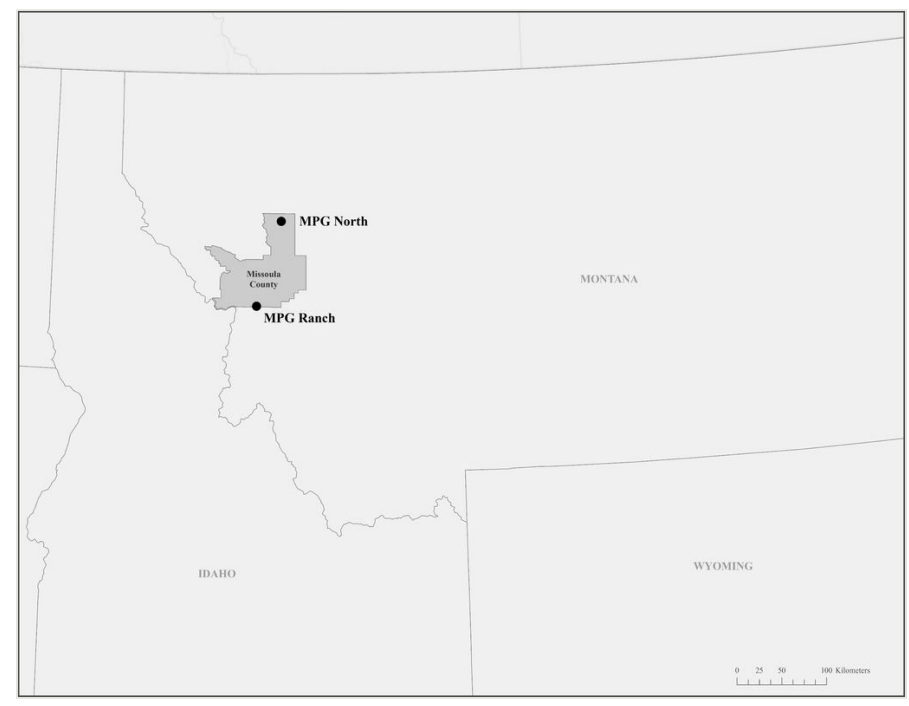

Figure 1.

Map of Montana and surrounding states with Missoula County boundary and property locations marked.

The MPG North, an associated 81 hectare conservation property separated from MPG Ranch by over 100 kilometers, is located in the Swan River Valley, also in Missoula County (Fig. 1), at an elevation of $1200 \mathrm{~m}$. The climate in the Swan River Valley is cooler and wetter than the Bitterroot River Valley. At the nearby town of Seeley Lake, mean temperatures range from $-6.1^{\circ} \mathrm{C}$ in December to $17.5^{\circ} \mathrm{C}$ in July, and mean annual preciptiation is $530 \mathrm{~mm}$. MPG North's habitat consists of mixed-conifer forest and clearings, and some small wetlands.

\section{Collection Methods}

We captured bees from MPG Ranch using the protocol outlined in A Standardized Method for Monitoring Bee Populations: The Bee Inventory (BI) Plot (LeBuhn et al. 2003), modified by reducing the amount of time spent netting from 60 minutes to 30 minutes. We used 24 plots that had been chosen for a larger, multi-organism surveying effort occurring on the property. These 24 sampling plots were placed along an elevational gradient, from approximately $975 \mathrm{~m}$ elevation to $1850 \mathrm{~m}$ elevation. At each location we laid out two $50 \mathrm{~m}$ transects, intersecting at 25m, creating an "X". We deployed 21, 3.25oz Solo brand plastic cups (Solo brand stock number PB6-0099) filled with soapy water at each sampling plot and placed them about $5 \mathrm{~m}$ apart along the transects. Bowls were spray-painted fluorescent 
blue, fluorescent yellow, or left white. Seven bowls of each of the three colors were used at each site. With the exception of the first sampling round, we placed traps out at all sampling plots on the same day by $9 \mathrm{am}$ and collected the contents after 3pm, providing a snapshot of the bee species composition for that day. We seived bowl-trapped bees in the field and transferred them into $40 z$ Whirl-Pak bags with $70 \%$ isopropanol. We kept these samples refrigerated until shipment to the USDA-ARS Pollinating Insects Research Unit in Logan, UT, for identification. A total of 30 minutes of netting occurred at each site on each collection day in 2013 and 2015, when time and field staff availability permitted. Netting took place on bowl-trapping days or the following day, and was limited to a $100 \mathrm{~m}$ radius of plot center. Samplers netted bees throughout the plot and attempted to sample from as many different floral resources as possible within the time frame. Netted bees were dispatched with ethyl acetate and kept frozen in labeled collection tubes until processed.

We sampled every 2-4 weeks throughout as much of the field season as possible to capture as much of the bee fauna as we could. We sampled each of the plots five times in 2013 (June 10-17, July 1, July 22, August 12, and September 9), seven times in 2014 (May 1 , May 15, June 12, July 10, July 31, August 28, and September 17), and nine times in 2015 (April 21, May 4, May 18, June 8, June 29, July 20, August 10, September 1, and September 23).

Collecting events at MPG North were part of a pilot study and consisted of a small number of blue vane trap collections and some hand-netting in 2014 and 2015. Bee species caught at MPG North are included in this species checklist.

Species accumulation estimates were determined by using EstimateS (Colwell 2013).

\section{Species Identification}

Bees were identified by Skyler Burrows with help from Harold Ikerd, Zachary Portman, Michael Orr, and Terry Griswold. Family, genus, and subgenus classifications follow Michener 2007 except in the some of the Lasioglossum subgenera (which follow Gibbs et al. 2012). Species determinations were made using the following taxonomic keys: Colletidae (Snelling 1966a, Snelling 1966b, Snelling 1970, Stephen 1954), Andrenidae (Bouseman and LaBerge 1978, LaBerge and Bouseman 1970, LaBerge 1969, LaBerge 1973, LaBerge and Ribble 1975, LaBerge 1977, LaBerge 1980, LaBerge 1985, LaBerge 1986, LaBerge 1989, Ribble 1967, Ribble 1974, Thorp 1969, Timberlake 1956, Timberlake 1960) Halictidae (Dumesh and Sheffield 2012, McGinley 1986, McGinley 2003, Roberts 1972, Roberts 1973), Megachilidae (Baker 1975, Gonzalez and Griswold 2013, Grigarick and Stange 1968, Hurd and Michener 1955, Michener 1938a, Michener 1938b, Michener 1939, Hurd 1958, Michener 1947, Sandhouse 1939, Sheffield et al. 2011), Apidae (Brumley 1965, Daly 1973, Koch et al. 2012, Hurd and Linsley 1951, LaBerge 1956a, LaBerge 1956b, LaBerge 1961, Laberge 1963, Rightmyer 2008, Sipes 2001, Thorp and Horning 1983, Timberlake 1969). In addition, reference specimens from the U.S. National Pollinating Insect Collection were used for species verification and identification. 
Bees that could be morphologically distinguished from each other but lacked taxonomic literature to determine species level were separated into morphospecies and given alphanumeric titles. When male and female morphospecies could not be associated, male morphospecies were given letters (e.g Nomada sp. A) and female morphospecies were given numbers (eg. Lasioglossum sp. 01). We only included the gender with the larger number of morphospecies in our species counts to avoid falsely inflating the number of species.

Bee specimens were pinned and labeled with location information, date, collection method, and collector name. Except for two synoptic sets of voucher specimens that are kept at MPG Ranch, specimens are deposited in the U.S. National Pollinating Insect Collection at Logan, Utah.

Lasioglossum bees in the subgenus Dialictus were identified only to subgenus due to the difficulty in distinguishing between Dialictus species and the lack of comprehensive keys for the western United States. Species in the genus Sphecodes were also only identified to genus level due to the lack of available taxonomic literature for the area.

\section{Range}

Species ranges were determined using Global Biodiversity Information Facility (GBIF), DiscoverLife.org (Ascher and Pickering 2016), and U.S. National Pollinating Insects databases in order to determine how many species records were new to the state of Montana.

\section{Checklist}

\section{Family Colletidae}

Colletes consors subsp. consors Cresson 1868

Colletes phaceliae Cockerell 1906

Colletes fulgidus subsp. fulgidus Swenk 1904

\section{Colletes kincaidii Cockerell 1898}

Hylaeus (Hylaeus) annulatus (Linnaeus 1758)

$$
\text { Hylaeus (Hylaeus) conspicuus (Metz 1911) }
$$


Hylaeus (Hylaeus) mesillae (Cockerell 1896)

Hylaeus (Paraprosopis) coloradensis (Cockerell 1896)

Hylaeus (Paraprosopis) wootoni (Cockerell 1896)

Hylaeus (Prosopis) modestus subsp. citrinifrons (Cockerell 1896)

Family Andrenidae

Andrena (Andrena) milwaukeensis Graenicher 1903

Andrena (Andrena) schuhi LaBerge 1980

Notes: New species record for Montana

Andrena (Andrena) thaspii Graenicher 1903

Andrena (Andrena) vicinoides Viereck 1904

Andrena (Andrena) sp. A

Andrena (Diandrena) evoluta Linsley \& MacSwain 1961

Notes: New species record for Montana

Andrena (Euandrena) astragali Viereck \& Cockerell 1914

Andrena (Euandrena) lawrencei Viereck \& Cockerell 1914

Andrena (Euandrena) nigrihirta (Ashmead 1890)

Andrena (Euandrena) nigrocaerulea Cockerell 1897

Andrena (Holandrena) cressonii Robertson 1891

Andrena (Leucandrena) barbilabris (Kirby 1802)

Andrena (Melandrena) nivalis Smith 1853 
Andrena (Melandrena) transnigra Viereck 1904

Andrena (Melandrena) vicina Smith 1853

Andrena (Micrandrena) chlorogaster Viereck 1904

Notes: New species record for Montana

Andrena (Micrandrena) illinoiensis Robertson 1891

Andrena (Micrandrena) melanochroa Cockerell 1898

Notes: New species record for Montana

Andrena (Micrandrena) microchlora Cockerell 1922

Andrena (Micrandrena) piperi Viereck 1904

Notes: New species record for Montana

Andrena (Micrandrena) cf. robinsoni Lanham 1987

Andrena (Plastandrena) crataegi Robertson 1893

Andrena (Plastandrena) prunorum Cockerell 1896

Andrena (Scaphandrena) merriami Cockerell 1901

Andrena (Scaphandrena) scurra Viereck 1904

Andrena (Scaphandrena) sladeni Viereck 1924

Notes: New species record for Montana

Andrena (Simandrena) angustitarsata Viereck 1904

Andrena (Simandrena) pallidifovea (Viereck 1904)

Andrena (Thysandrena) candida Smith 1879 
Andrena (Thysandrena) medionitens Cockerell 1902

Andrena (Thysandrena) w-scripta Viereck 1904

Andrena (Trachandrena) amphibola (Viereck 1904)

Andrena (Trachandrena) cupreotincta Cockerell 1901

Andrena (Trachandrena) forbesii Robertson 1891

Andrena (Trachandrena) miranda Smith 1879

Andrena (Trachandrena) salicifloris Cockerell 1897

Andrena (Tylandrena) subtilis Smith 1879

Calliopsis xenus (Rozen 1958)

Notes: New species record for Montana

Panurginus atriceps (Cresson 1878)

Panurginus sp. 01

Perdita (Perdita) fallax Cockerell 1896

Perdita (Perdita) swenki Crawford 1915

Notes: New species record for Montana

Perdita (Pygoperdita) wyomingensis subsp. segona Timberlake 1956

Pseudopanurgus didirupa (Cockerell 1908)

Notes: New species record for Montana

Family Halictidae

Agapostemon (Agapostemon) obliquus (Provancher 1888)

Notes: New species record for Montana 
Agapostemon (Agapostemon) texanus Cresson 1872

Agapostemon (Agapostemon) virescens (Fabricius 1775)

Dufourea holocyanea (Cockerell 1925)

Dufourea maura (Cresson 1878)

Dufourea trochantera Bohart 1948

Halictus (Nealictus) farinosus Smith 1853

Halictus (Odontalictus) ligatus Say 1837

Halictus (Protohalictus) rubicundus (Christ 1791)

Halictus (Seladonia) confusus Smith 1853

Halictus (Seladonia) tripartitus Cockerell 1895

Lasioglossum (Dialictus) sp.

Lasioglossum (Hemihalictus) glabriventre (Crawford 1907)

Lasioglossum (Hemihalictus) inconditum (Cockerell 1916)

Lasioglossum (Hemihalictus) kincaidii (Cockerell 1898)

Notes: New species record for Montana

Lasioglossum (Hemihalictus) ovaliceps (Cockerell 1898)

Notes: New species record for Montana

Lasioglossum (Hemihalictus) ruficorne (Crawford 1907)

Notes: New species record for Montana

Lasioglossum (Hemihalictus) sp. 1

Lasioglossum (Hemihalictus) sp. 2 
Lasioglossum (Hemihalictus) sp. 3

Lasioglossum (Hemihalictus) sp. 4

Lasioglossum (Lasioglossum) anhypops McGinley 1986

Lasioglossum (Lasioglossum) athabascense (Sandhouse 1933)

Lasioglossum (Lasioglossum) egregium (Vachal 1904)

Lasioglossum (Lasioglossum) paraforbesii McGinley 1986

Lasioglossum (Lasioglossum) sisymbrii (Cockerell 1895)

Lasioglossum (Lasioglossum) trizonatum (Cresson 1874)

Lasioglossum (Lasioglossum) zonulum (Smith 1848)

Lasioglossum (Sphecodogastra) cooleyi (Crawford 1906)

Lasioglossum (Sphecodogastra) lusoria (Cresson 1872)

Sphecodes sp.

Family Megachilidae

Anthidium (Anthidium) atrifrons Cresson 1868

Anthidium (Anthidium) mormonum Cresson 1878

Anthidium (Anthidium) utahense Swenk 1914

Ashmeadiella (Ashmeadiella) bucconis (Say 1837)

Ashmeadiella (Ashmeadiella) cactorum (Cockerell 1897)

Ashmeadiella (Ashmeadiella) californica (Ashmead 1897)

Notes: New species record for Montana 
Ashmeadiella (Ashmeadiella) cubiceps (Cresson 1879)

Notes: New species record for Montana

Atoposmia (Atoposmia) elongata (Michener 1936)

Chelostoma (Chelostoma) minutum Crawford 1916

Notes: New species record for Montana

Coelioxys (Boreocoelioxys) banksi Crawford 1914

Coelioxys (Boreocoelioxys) moesta Cresson 1864

Coelioxys (Boreocoelioxys) octodentata Say 1824

Coelioxys (Boreocoelioxys) rufitarsis Smith 1854

Coelioxys (Cyrtocoelioxys) modesta Smith 1854

Coelioxys (Xerocoelioxys) edita Cresson 1872

Notes: New species record for Montana

Coelioxys (Xerocoelioxys) grindeliae Cockerell 1900

Dianthidium (Dianthidium) curvatum (Smith 1854)

Dianthidium (Dianthidium) pudicum (Cresson 1879)

Dianthidium (Dianthidium) subparvum Swenk 1914

Dianthidium (Dianthidium) ulkei (Cresson 1878)

Dioxys pomonae Cockerell 1910

Notes: New species record for Montana

Heriades (Neotrypetes) carinatus Cresson 1864 
Heriades (Neotrypetes) variolosus (Cresson 1872)

Hoplitis (Alcidamea) grinnelli Cockerell 1910

Notes: New species record for Montana

Hoplitis (Alcidamea) pilosifrons (Cresson 1864)

Hoplitis (Alcidamea) producta (Cresson 1864)

Hoplitis (Alcidamea) sambuci Titus 1904

Notes: New species record for Montana

Hoplitis (Cyrtosmia) hypocrita (Cockerell 1906)

Hoplitis (Monumetha) albifrons (Kirby 1837)

Hoplitis (Monumetha) fulgida subsp. fulgida (Cresson 1864)

Megachile (Argyropile) parallela Smith 1853

Megachile (Chelostomoides) angelarum Cockerell 1902

Notes: New species record for Montana

Megachile (Eutricharaea) apicalis Spinola 1808

Notes: New species record for Montana

Megachile (Eutricharaea) rotundata (Fabricius 1793)

Megachile (Litomegachile) brevis Say 1837

Megachile (Litomegachile) coquilletti Cockerell 1915

Notes: New species record for Montana

Megachile (Litomegachile) lippiae Cockerell 1900

Megachile (Litomegachile) onobrychidis Cockerell 1905 
Megachile (Megachile) lapponica Thomson 1872

Megachile (Megachile) montivaga Cresson 1878

Megachile (Megachile) relativa Cresson 1878

Megachile (Megachiloides) pascoensis Mitchell 1934

Megachile (Sayapis) fidelis Cresson 1878

Megachile (Sayapis) pugnata Say 1837

Megachile (Xanthosarus) melanophaea Smith 1853

Megachile (Xanthosarus) perihirta Cockerell 1898

Osmia (Acanthosmioides) integra Cresson 1878

Osmia (Acanthosmioides) longula Cresson 1864

Osmia (Cephalosmia) californica Cresson 1864

Osmia (Cephalosmia) marginipennis Cresson 1878

Osmia (Cephalosmia) montana subsp. montana Cresson 1864

Osmia (Helicosmia) coloradensis Cresson 1878

Osmia (Melanosmia) albolateralis Cockerell 1906

Osmia (Melanosmia) atrocyanea Cockerell 1897

Osmia (Melanosmia) austromaritima Michener 1936

Notes: New species record for Montana

Osmia (Melanosmia) brevis Cresson 1864

Osmia (Melanosmia) bruneri Cockerell 1897 
Osmia (Melanosmia) calla Cockerell 1897

Osmia (Melanosmia) cyaneonitens Cockerell 1906

Osmia (Melanosmia) densa Cresson 1864

Osmia (Melanosmia) ednae Cockerell 1907

Osmia (Melanosmia) juxta Cresson 1864

Osmia (Melanosmia) kincaidii Cockerell 1897

Notes: New species record for Montana

Osmia (Melanosmia) melanopleura Cockerell 1916

Notes: New species record for Montana

Osmia (Melanosmia) paradisica Sandhouse 1924

Osmia (Melanosmia) proxima Cresson 1864

Osmia (Melanosmia) pusilla Cresson 1864

Osmia (Melanosmia) trevoris Cockerell 1897

Osmia (Melanosmia) tristella Cockerell 1897

Osmia (Mystacosmia) nemoris Sandhouse 1924

Osmia (Osmia) lignaria subsp. propinqua Cresson 1864

Stelis (Stelis) aff. Ashmeadiellae Timberlake 1941

Stelis (Stelis) aff. holocyanea (Cockerell 1925)

Stelis (Stelis) lateralis Cresson 1864

Stelis (Stelis) montana Cresson 1864 
Stelis (Stelis) sp. 01

Family Apidae

Anthophora (Clisodon) terminalis Cresson 1869

Anthophora (Lophanthophora) pacifica Cresson 1878

Notes: New species record for Montana

Anthophora (Lophanthophora) porterae Cockerell 1900

Anthophora (Lophanthophora) ursina Cresson 1869

Anthophora (Melea) bomboides Kirby 1838

Anthophora (Melea) occidentalis Cresson 1869

Anthophora (Mystacanthophora) urbana Cresson 1878

Anthophora (Mystacanthophora) walshii Cresson 1869

Notes: New species record for Montana

Apis mellifera Linnaeus 1758

Bombus (Bombias) nevadensis Cresson 1874

Bombus (Bombus) occidentalis Greene 1858

Bombus (Cullumanobombus) rufocinctus Cresson 1863

Bombus (Fervidobombus) californicus Smith 1854

Bombus (Fervidobombus) fervidus (Fabricius 1798)

Bombus (Psithyrus) fernaldae (Franklin 1911)

Bombus (Psithyrus) insularis (Smith 1861) 
Bombus (Pyrobombus) bifarius Cresson 1878

Bombus (Pyrobombus) centralis Cresson 1864

Bombus (Pyrobombus) flavifrons Cresson 1863

Bombus (Pyrobombus) huntii Greene 1860

Bombus (Pyrobombus) mixtus Cresson 1878

Bombus (Pyrobombus) vagans Smith 1854

Bombus (Subterraneobombus) appositus Cresson 1878

Ceratina (Zadontomerus) acantha Provancher 1895

Notes: New species record for Montana

Ceratina (Zadontomerus) nanula Cockerell 1897

Ceratina (Zadontomerus) neomexicana Cockerell 1901

Diadasia diminuta (Cresson 1878)

Epeolus aff. americanus (Cresson 1878)

Epeolus compactus Cresson 1878

Epeolus minimus (Robertson 1902)

Notes: New species record for Montana

Epeolus sp. 01

Eucera (Synhalonia) edwardsii (Cresson 1878)

Eucera (Synhalonia) frater subsp. lata (Provancher 1888)

Eucera (Synhalonia) fulvitarsis (Cresson 1878) 
Eucera (Synhalonia) hurdi (Timberlake 1969)

Notes: New species record for Montana

Habropoda cineraria (Smith 1879)

Melecta (Melecta) pacifica Cresson 1878

Melecta (Melecta) separata Cresson 1879

Melecta (Melecta) thoracica Cresson 1875

Notes: New species record for Montana

Melissodes (Callimelissodes) composita Tucker 1909

Melissodes (Callimelissodes) lupina Cresson 1878

Melissodes (Callimelissodes) sp. 1

Melissodes (Eumelissodes) agilis Cresson 1878

Melissodes (Eumelissodes) nr. microsticta Cockerell 1905

Melissodes (Eumelissodes) sp. 2

Melissodes (Heliomelissodes) rivalis Cresson 1872

Neopasites (Neopasites) fulviventris (Cresson 1873)

Notes: New species record for Montana

Nomada sp. 01

Nomada sp. 02

Nomada sp. 03

Nomada sp. 04 
Nomada sp. 05

Nomada sp. 06

Nomada sp. 07

Nomada sp. 08

Nomada sp. 09

Nomada sp. 10

Nomada sp. 11

Nomada sp. 12

Nomada sp. A

Nomada sp. B

Nomada sp. C

Nomada sp. D

Nomada sp. E

Nomada sp. F

Nomada sp. G

Nomada sp. $\mathrm{H}$

Nomada sp. I

Nomada sp. J

Nomada sp. K 


\section{Nomada sp. L}

Nomada sp. M

Nomada sp. N

Nomada sp. 0

Nomada scita Cresson 1878

Triepeolus heterurus (Cockerell \& Sandhouse 1924)

Notes: New species record for Montana

Triepeolus aff. micropygius Robertson 1903

Triepeolus paenepectoralis (Viereck 1905)

Triepeolus sp. 01

Xeromelecta (Melectomorpha) californica (Cresson 1878)

\section{Analysis}

Between 2013 and 2015 we collected a total of 64,747 bees representing 229 species and morphospecies across 38 genera in 5 bee families (Suppl. material 1). We had a total of 558 collection events (unique combinations of site and collection date). The number of species we collected is near the number of species we would expect to find in our study area based on species accumulation estimates, which predict the number of bee species in the area to be 255 (Fig. 2). Net collections yielded a total of 110 species, only three of which were species not also collected by pantraps. This number is lower than would be expected based on previous studies showing from $23 \%$ and $53 \%$ of the bee species collected by net to be unique when compared to pantraps (Grundel et al. 2011, Roulston et al. 2007, Wilson et al. 2008). This may be due to the reduced net collection time period (30 minutes instead of 60 minutes). In addition, many of the net collectors had no prior experience with insect collecting. Increased collection periods and improved collector training could raise the number of unique net collected species. 


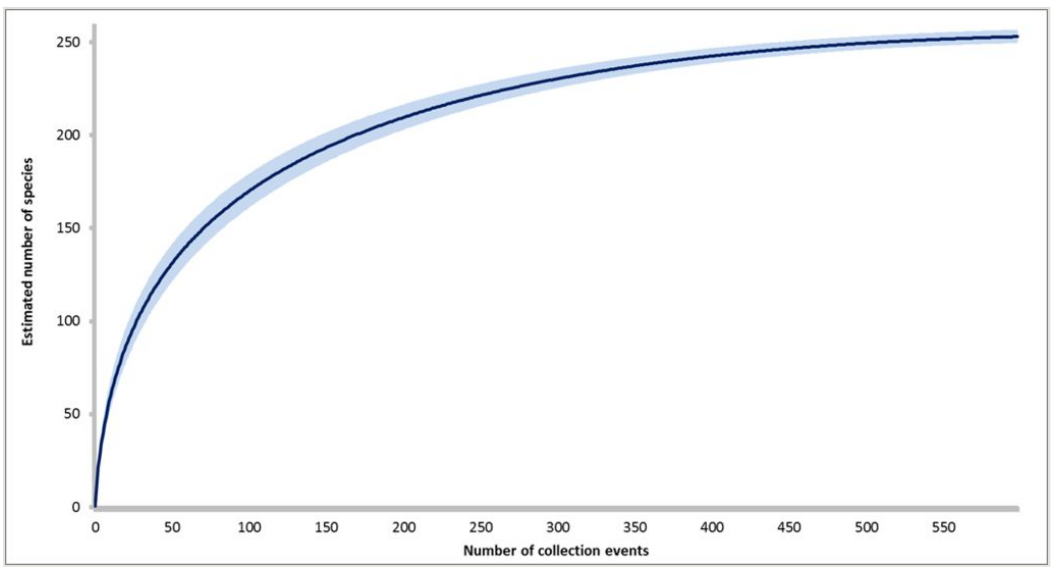

Figure 2.

Species accumulation curve generated for bee species sampled in 558 collection events between 2013 and 2015. Species estimates were generated using EstimateS. The blue line represents the mean species accumulation, and the light blue shaded area represents the upper and lower bound of $95 \%$ confidence interval for species estimate.

\section{Discussion}

Prior to our investigation, the number of known wild bee species in Montana was 337. Our study increases this number to a total of 366 . This result may not be unexpected since Montana is largely rural and there have been few large scale bee inventories in the state. Fewer than 1200 collected bee specimens have been reported each year in Montana prior to 2013 (GBIF 2016, U. S. National Pollinating Insects Database 2016). Our species list is relevant to other areas within the Montana Valley and Foothill Prairies Ecoregion (Taylor 2012), but may not reflect bee species present in other ecoregions in Montana, especially the Northwestern Great Plains and Northwestern Glaciated Plains Ecoregions. Investigations in the sparsely populated central and eastern portions of Montana may yield more species to a state bee species checklist.

\section{Megachile apicalis}

Megachile apicalis is an Old World species in the subgenus Eutricharaea. Although there are North American records for $M$. apicalis prior to 1932, no established populations were recorded until 1984, when resident populations were documented in Santa Barbara County, CA (Cooper 1984). Subsquent collections showed that the species had expanded its range to Oregon, Washington, and British Columbia, Canada, along with its most common floral host, Centaurea solstitialis (Barthell et al. 2001, Mclver et al. 2009, Sheffield et al. 2011), a widespread, introduced weed that invades rangelands in the western United States. There is evidence for a positive link between the spread of non-native weeds and the presence of non-native bees (Hanley and Goulson 2003). Megachile apicalis has a 
strong association with $C$. solstitialis and some researchers have suggested that these two Old World species, along with Apis mellifera, form an invasive mutualism (Barthell et al. 2001, Mclver et al. 2009), in which each of the three species within the mutualism benefits from the presence of, and encourages the spread of the other species within the mutualism. Our collections are the first documentation of $M$. apicalis in Montana, indicating further range expansion of this adventive bee. Centaurea stoebe, a close relative of $C$. solstitialis, is a problematic weed species throughout MPG Ranch and Montana. Megachile apicalis captures increase in late summer/early autumn, when Centaurea stoebe bloom intensity peaks (MPG Ranch unpublished data), suggesting that $M$. apicalis may be preferentially using this Centaurea species in our area. Additionally, M. apicalis appears to be integrated throughout the MPG Ranch, since we have found M. apicalis at most of our sampling locations.

\section{Acknowledgements}

Many thanks to the MPG Field Crew for their assistance with bee collections, as well as several summer interns and other seasonal field staff. Debbie Leick created the map for Figure 1. Zach Portman helped with Perdita identifications and provided feedback on this manuscript. Dr. Terry Griswold and Harold Ikerd provided insight, encouragement, identification assistance, and many helpful discussions. The USDA-ARS Bee Biology and Systematics Laboratory provided lab space, specimen storage, and use of reference collections. Dr. Philip Ramsey, manager of MPG Ranch, allowed for procurement of the resources necessary to carry out sampling. We would also like to thank Jack Neff, Cory Sheffield, and Michael Kuhlmann for taking the time to review this manuscript and providing helpful feedback and suggestions. Finally, thanks to the Gurinas family for ongoing financial support of this project.

\section{Author contributions}

Kuhlman initiated the project, conducted the surveys, and prepared specimens for shipment. Burrows processed, identified, and archived all the specimens. Both authors participated in writing this manuscript.

\section{References}

- $\quad$ Ascher J, Pickering J (2016) Discover Life bee species guide and world checklist (Hymenoptera: Apoidea: Anthophila). Discoverlife.org. Accessed on: 2016-10-06.

- $\quad$ Baker JR (1975) Taxonomy of five nearctic subgenera of Coelioxys (Hymenoptera: Megachilidae). University of Kansas Science Bulletin 50 (12): 649-73.

- $\quad$ Barthell J, Randall J, Thorp R, Wenner A (2001) Promotion of seed set in yellow starthistle by honey bees: evidence of an invasive mutualism. Ecological Applications 11 (6): 1870-1883. https://doi.org/10.1890/1051-0761(2001)011[1870:POSSIY]2.0.CO;2 
- Bouseman JK, LaBerge WE (1978) A revision of the bees of the genus Andrena of the Western Hemisphere. Part IX. Subgenus Melandrena. Transactions of the American Entomological Society 104 (3): 275-38.

- Brumley RL (1965) A revision of the bee genus Epeolus of western America north of Mexico. Masters thesis, Utah State University, Dept. of Biology, Logan, 92 pp.

- $\quad$ Colwell RK (2013) EstimateS: Statistical estimation of species richness and shared species from samples. Version 9. User's Guide and application. http://purl.oclc.org/ estimates.

- Cooper K (1984) Discovery of the first resident population of the European bee, Megachile apicalis in the United States (Hymenoptera: Megachilidae). Entomological News 95 (5): 225-226.

- Daly HV (1973) Bees in the genus Ceratina in America north of Mexico. University of California Publications in Entomology 74: 1-117.

- Dumesh S, Sheffield CS (2012) Bees of the genus Dufourea Lepeletier (Hymenoptera: Halictidae: Rophitinae) of Canada. Canadian Journal of Arthropod Identification 20: 1-36.

- $\quad$ GBIF (2016) (19th August 2016) GBIF Occurrence Download. Global Biodiversity Information Facility, https://doi.org/http://doi.org/10.15468/dl.5ixvmp. GBIF.org

- Gibbs J, Packer L, Dumesh S, Danforth BN (2012) Revision and reclassification of Lasioglossum (Evylaeus), L. (Hemihalictus) and L. (Sphecodogastra) in eastern North America (Hymenoptera: Apoidea: Halictidae). Zootaxa 3672: 1-117. https:// doi.org/10.11646/zootaxa.3672.1.1

- Gonzalez VH, Griswold TL (2013) Wool carder bees of the genus Anthidium in the Western Hemisphere (Hymenoptera: Megachilidae, Anthidiini) with a phylogenetic analysis of the subgenera. Zoological Journal of the Linnean Society 168 (2): 221-425. https://doi.org/10.1111/zoj.12017

- $\quad$ Grigarick AA, Stange LA (1968) Pollen-collecting bees of the Anthidiini of California (Hymenoptera: Megachilidae). Bulletin of the California Insect survey 9: 1-113.

- $\quad$ Grundel R, Frohnapple K, Jean R, Pavlovic N (2011) Effectiveness of Bowl Trapping and Netting for Inventory of a Bee Community. Environmental Entomology 40 (2): 374-380. https://doi.org/10.1603/en09278

- Hanley ME, Goulson D (2003) Introduced weeds pollinated by introduced bees: Cause or effect? Weed Biology and Management 3: 204-212. https://oi.org/10.1046/ j.1444-6162.2003.00108.x

- Hurd PD (1958) American bees of the genus Dioxys Lepeletier and Serville (Hymenoptera: Megachilidae). University of California Publications in Entomology 14 (4): 275-302.

- Hurd PD, Linsley EG (1951) The Melectine bees of California. Bulletin of the California Insect Survey 1 (5): 119-140.

- Hurd PD, Michener CD (1955) The megachiline bees of California (Hymenoptera: Megachilidae). Bulletin of the California Insect Survey 3: 1-247.

- Koch JB, Strange JP, Williams PH (2012) Bumble bees of the western United States. US Forest Service, $143 \mathrm{pp}$.

- Laberge WE (1963) New species and records of little-known species of Melissodes from North America (Hymenoptera: Anthophoridae). University of Nebraska State Museum 4 (10): 227-242. 
- LaBerge WE (1956a) A Revision of the bees of the genus Melissodes in North and Central America: Part I (Hymenoptera, Apidae). University of Kansas Science Bulletin 37 (18): 911-1194. https://doi.org/10.5962/bhl.part.24549

- LaBerge WE (1956b) A Revision of the bees of the genus Melissodes in North and Central America: Part II (Hymenoptera, Apidae). University of Kansas Science Bulletin 38 (8): 533-578.

- LaBerge WE (1961) A Revision of the Bees of the Genus Melissodes in North and Central America: Part III (Hymenoptera, Apidae). University of Kansas Science Bulletin 42 (5): 283-663. https://doi.org/10.5962/bhl.part.9821

- LaBerge WE (1969) A revision of the bees of the genus Andrena of the Western Hemisphere. Part II. Plastandrena, Aporandrena, Charitandrena. Transactions of the American Entomological Society 95 (1): 1-47.

- LaBerge WE (1973) A revision of the bees of the genus Andrena of the western hemisphere. Part VI. Subgenus Trachandrena. Transactions of the American Entomological Society 99 (3): 235-371.

- LaBerge WE (1977) A revision of the bees of the genus Andrena of the western hemisphere. Part VIII. Subgenera Thysandrena, Dasyandrena, Psammandrena, Rhacandrena, Euandrena, Oxyandrena. Transactions of the American Entomological Society 103 (1): 1-143.

- LaBerge WE (1980) A revision of the bees of the genus Andrena of the western hemisphere. Part X. Subgenus Andrena . Transactions of the American Entomological Society 106 (4): 395-525.

- LaBerge WE (1985) A revision of the bees of the genus Andrena of the western hemisphere. Part XI. Minor subgenera and subgeneric key. Transactions of the American Entomological Society 111 (4): 441-567.

- LaBerge WE (1986) A revision of the bees of the genus Andrena of the Western Hemisphere. Part XII. Subgenera Leucandrena, Ptilandrena, Scoliandrena and Melandrena. Transactions of the American Entomological Society 112 (3): 191-248.

- LaBerge WE (1989) A revision of the bees of the genus Andrena of the western hemisphere. Part XIII. Subgenera Simandrena and Taeniandrena. Transactions of the American Entomological Society 115 (1): 1-56.

- LaBerge WE, Bouseman JK (1970) A revision of the bees of the genus Andrena of the Western Hemisphere. Part III. Tylandrena. Transactions of the American Entomological Society 96 (4): 543-605.

- $\quad$ LaBerge WE, Ribble DW (1975) A revision of the bees of the genus Andrena of the western hemisphere. Part VII. Subgenus Euandrena. Transactions of the American Entomological Society 101 (3): 371-44.

- LeBuhn G, Griswold T, Minckley R, Droege S, Roulston T, Cane J, Parker F, Buchmann S, Tepedino V, Williams N, Kremen C, Messenger O (2003) A standardized method for monitoring bee populations - The Bee Inventory (BI) Plot. http://online.sfsu.edu/beeplot/ pdfs/Bee\%20Plot\%202003.pdf. Accessed on: 2016-9-20.

- McGinley RJ (1986) Studies of Halictinae (Apoidea: Halictidae) I: Revision of New World Lasioglossum . Smithsonian contributions to zoology 429: 1-294.

- McGinley RJ (2003) Studies of Halictinae (Apoidea: Halictidae) II: Revision of Sphecodogastra, floral specialists of Onagraceae . Smithsonian contributions to zoology 168 (2): 221-425. 
- $\quad$ Mclver J, Thorp R, Erickson K (2009) Pollinators of the invasive plant, Yellow Starthistle (Centaurea solstitialis), in north-eastern Oregon, USA. Weed Biology and Management 9: 137-145. https://doi.org/10.1111/j.1445-6664.2009.00331.x

- $\quad$ Menz MM, Phillips R, Winfrey R, Kremen C, Aileen M, Johnson S, Dixon K (2011) Reconnecting plants and pollintors: challenges in the restoration of pollination mutualisms. Trends in Plant Science 16 (1): 4-12. https://doi.org/10.1016/ j.tplants.2010.09.006

- $\quad$ Messinger O, Griswold T (2002) A pinnacle of bees. Fremontia 30 (3): 30-40. URL: http://www.cnps.org/cnps/publications/fremontia/Fremontia Vol30-No3and4.pdf

- Michener CD (1938a) American bees of the genus Heriades. Annals of the Entomological Society of America 31 (4): 514-530. https://doi.org/10.1093/ aesa/31.4.514

- $\quad$ Michener CD (1938b) American bees of the genus Chelostoma . Pan-Pacific Entomologist 14 (1): 36-46.

- Michener CD (1939) A revision of the genus Ashmeadiella (Hymenoptera, Megachilidae). The American Midland Naturalist 22 (1): 1-84. https:// doi.org/10.2307/2420397

- Michener CD (1947) A revision of the American species of Hoplitis (Hymenoptera, Megachilidae). American Museum of Natural History 89 (4): 261-317.

- Michener CD (2007) Bees of the World. 2nd ed. Johns Hopkins, Baltimore and London, $953 \mathrm{pp}$.

- $\quad$ Ribble DW (1967) Revisions of two subgenera of Andrena: Micrandrena and Derandrena, New subgenus (Hymenoptera: Apoidea). Bulletin of The University of Nebraska State Museum 8 (5): 237-394.

- Ribble DW (1974) A revision of the bees of the genus Andrena of the western hemisphere subgenus Scaphandrena. Transactions of the American Entomological Society 100 (2): 101-189.

- $\quad$ Rightmyer MG (2008) A review of the cleptoparasitic bee genus Triepeolus (Hymenoptera: Apidae). Part I. Zootaxa 1710: 1-170.

- Roberts RB (1972) Revision of the bee genus Agapostemon (Hymenoptera: Halictidae). University of Kansas Science Bulletin 49 (9): 437-590.

- $\quad$ Roberts RB (1973) Bees of northwestern America: Halictus (Hymenoptera: Halictidae). Corvallis: Agricultural Experiment Station, Oregon State University 1-23.

- $\quad$ Roulston T, Smith S, Brewster A (2007) A Comparison of Pan Trap and Intensive Net Sampling Techniques for Documenting a Bee (Hymenoptera: Apiformes) Fauna. Journal of the Kansas Entomological Society 80 (2): 179-181. https://doi.org/10.2317/0022-8567 (2007)80[179:acopta]2.0.co;2

- $\quad$ Sandhouse GA (1939) The North American bees of the genus Osmia (Hymenoptera: Apoidea). Memoirs of The Entomological Society of Washington 1: 1-167.

- $\quad$ Scott V, Ascher J, Griswold T, Nufio C (2011) The Bees of Colorado (Hymenoptera: Apioidae: Anthophila). 23. University of Colorado Museum of Natural History, Boulder, Colorado, 100 pp. URL: http://www.colorado.edu/cumuseum/sites/default/files/attachedfiles/the bees of colorado.pdf

- $\quad$ Sheffield C, Ratti C, Packer L, Griswold T (2011) Leaf-cutter and Mason Bees of the genus Megachile Latrielle (Hymenoptera: Megachilidae) in Canada and Alaska. Canadian Journal of Arthropod Identification 18: 1-107. 
- $\quad$ Sipes SD (2001) Phylogenetic relationships, taxonomy, and evolution of host choice in Diadasia (Hymenoptera: apoidea). Doctoral dissertation, Utah State University, Dept. of Biology, 58-151 pp.

- $\quad$ Snelling RR (1966a) Studies on North American bees of the genus Hylaeus 1. Distribution of the western species of the subgenus Prosopis with descriptions of new forms (Hymenoptera: Colletidae). Contributions in Science-Los Angeles County Museum 98: 1-18.

- $\quad$ Snelling RR (1966b) Studies on North American bees of the genus Hylaeus. 3. The Nearctic subgenera (Hymenoptera: Colletidae). Bulletin of the Southern California Academy of Sciences 65 (3): 164-175.

- $\quad$ Snelling RR (1970) Studies on North American bees of the genus Hylaeus. 5. The subgenera Hylaeus, s. str. and Paraprosopis (Hymenoptera: Colletidae). Contributions in Science-Los Angeles County Museum 180: 1-59.

- $\quad$ Stephen WP (1954) A revision of the bee genus Colletes in America north of Mexico (Hymenoptera, Colletidae). University of Kansas Science Bulletin 36 (1): 149-527.

- Taylor JL (2012) Montana Valley and Foothill Prairies Ecoregion. In: Sleeter BM, Wilson TS, Acevedo W (Eds) Status and Trends of Land Change in the Western U.S. - 1973 2000: U.S. Geological Survey Professional Paper 1794-A. 324 pp. URL: http:// pubs.usgs.gov/pp/1794/a/

- Tepedino VJ, Griswold TL (1995) The bees of the Columbia Basin. Final Report, USDA Forest Service, Portland, OR, $212 \mathrm{pp}$.

- Thorp RW (1969) Systematics and ecology of bees of the subgenus Diandrena (Hymenoptera: Andrenidae). University of California Publications in Entomology 52: 1-146.

- $\quad$ Thorp RW, Horning DS (1983) Bumble bees and cuckoo bumble bees of California (Hymenoptera, Apidae). Bulletin of the California Insect Survey 23: 1-79.

- Timberlake PH (1956) A revisional study of the bees of the genus Perdita F. Smith, with special reference to the fuana of the Pacific coast (Hymenoptera, Apoidea). Part II. University of California Publications in Entomology 11: 247-350.

- Timberlake PH (1960) A revisional study of the bees of the genus Perdita F. Smith, with special reference to the fuana of the Pacific coast (Hymenoptera, Apoidea). Part IV. University of California Publications in Entomology 17: 1-156.

- Timberlake PH (1969) A contribution to the systematics of North American species of Synhalonia (Hymenoptera, Apoidea). University of California Publications in Entomology 57: $1-7$.

- U. S. National Pollinating Insects Database (2016) United States Department of Agriculture, Agriculture Research Service, Bee Biology and Systematics Laboratory, Logan, Utah (Accessed 2016-06-10).

- Williams N (2011) Restoration of Nontarget Species: Bee Communities and Pollination Function in Riparian Forests. Restoration Ecology 19 (4): 450-45. https:// doi.org/10.1111/j.1526-100X.2010.00707.x

- Wilson J, Griswold T, Messinger O (2008) Sampling Bee Communities (Hymenoptera: Apiformes) in a Desert Landscape: Are Pan Traps Sufficient? Journal of the Kansas Entomological Society 81 (3): 288-300. https://doi.org/10.2317/jkes-802.06.1

- Wilson J, Wilson L, Loftis L, Griswold T (2010) The montane bee fauna of north central Washington, USA, with floral associations. Western North American Naturalist 70 (2): 198-207. https://doi.org/10.3398/064.070.0206 


\section{Supplementary material}

Suppl. material 1: MPG species with male and female counts

Authors: Burrows, S.J. \& Kuhlman M.

Data type: Occurence

Brief description: MPG species list with number of males and females of each species collected from 2013-2015.

Filename: MPG species with male and female counts.xlsx - Download file (19.86 kb) 